\title{
PERBUATAN MELAWAN HUKUM DALAM PENAGIHAN UTANG KARTU KREDIT OLEH DEBT COLLECTOR DAN PERTANGGUNGJAWABAN BANK
}

\author{
Oleh: Nanin Koeswidi Astuti \\ naninkoeswidi@yahoo.co.id \\ Universitas Kristen Indonesia, Jakarta, Indonesia
}

\begin{abstract}
Consumer nancing business in the form of Credit Card as a form of less cash society is developing in Indonesia has even become a culture in modern society coupled with the support of fast payment system, safe, ef cient and reliable, smoothness in payment, providing legal certainty for the community in doing transaction, but consumer nance business though very attractive but does not mean this business has no risk at all, as credit giving, the risk will still exist at the time of stalled payment of credit card arrears by consumers. In the event of a consumer credit crunch, banks usually use debt collection services known as debt collectors. Often debt collectors in doing debt collection services work unprofessionally even sometimes tend to do acts against the law, so it will cause harm to customers and credit card issuing bank, because it is not in accordance with what is expected.
\end{abstract}

Keywords: payment system; Credit Card; debt collectors; accordance.

\section{Pendahuluan}

Perkembangan transaksi dengan memanfaatkan teknologi di kenal dengan e-commerce. Bentuk transaksi dengan menggunakan tehnologi informasi dalam bentuk electronic transaction (e-banking), baik melalui ATM, phone banking, internet banking, mobile banking maupun electronic mall yang memudahkan transaksi konsumen dengan cara yang canggih, modern dibandingkan dengan transaksi konvensional. Alat pembayaran konvensional yang dahulu berupa uang kertas, cek, giro, pada saat ini digantikanoleh kartu (cardbased) seperti kartu kredit, kartu debet atau kartu ATM dan juga dengan uang elektronik (electronic based) seperti $e$-money, $i$-banking, mobile banking dan electronic mall. Begitu juga hal nya dengan bisnis pembiayaan konsumen (consumer finance)dengan menggunakan kartu kredit (creditcard) ini sangat menarik minat masyarakat, karenalebih mudah mendapatkan kredit dibandingkan dengan mendapatkan kredit dari bank untuk kredit konsumsi. Dalam sistem pembiayaan konsumen, suatu perusahaan pembiayaan memberikan bantuan dana untuk membeli barang- barang konsumsi, misalnya mobil, motor, kulkas, televisi, radio, handphone, tas, baju, dan lainnya.

Kredit dapat dibagi menjadi 2 (dua) macam, sale credit dan loan credit, salecredit adalah pemberian kredit untukmembeli suaru barang dimana nasabah akan menerima barang yang dibeli, sedangkan loan credit adalah pemberian kredit kekonsumen dengan pemberian uang cash dan harus mengembalikan secara cash juga. Pembiayaan konsumen tergolong ke dalam sale credit, karana konsumen tidak menerima cash, tapi hanya menerima barang yangdibeli secara kredit. ${ }^{1}$

Perkembangan less cash society merupakan suatu trend yang tidak dapat dihindari, karena perputaran ekonomi sangat menuntut dukungan sistem pembayaran yang cepat, aman, efisien serta handal, kelancaran di dalam pembayaran, akan memberikan kepastian hukum bagi masyarakat di dalam melakukan transaksi. Penggunaan pembayaran non tunai dengan menggunakan kartu, selain mempermudah transaksi seperti penarikan tunai, transfer dana dan pembayaran 1 Munir Fuady, Hukum Tentang Pembiayaan, (Bandung: PT. Citra Aditya Bakti, 2014), hal. 163. 
berbagai tagihan rutin lainnya, tanpa perlu datang ke counter atau kantor bank. Dengan adanya pembayaran non tunai bank dapat memperkuat daya saing, memperluas pasar, meningkatkan fee based income dan memberikan layanan plus kepada nasabahnya. Selain itu operasional penyelesaian transaksi dan berbagai kebutuhan nasabah atau customer akan dapat cepat selesai dalam satu waktu, dengan biaya transaksi yang murah. $^{2}$

Penggunaan kartu kredit dalam perbankan di Indonesia dikenal dengan alat pembayaran menggunakan kartu (AMPK) sebagaimana yang tertuang dalam PBI/11/11/PBI/2009 Pasal 1 ayat 4, yaitu Kartu Kredit adalah APMK yang dapat digunakan untuk melakukan pembayaran atas kewajiban yang timbul dari suatu kegiatan ekonomi, termasuk transaksi pembelanjaan dan/atau untuk melakukan penarikan tunai, dimana kewajiban pembayaran pemegang kartu dipenuhi terlebih dahulu oleh acquirer atau penerbit, dan pemegang kartu berkewajiban untuk melakukan pembayaran pada waktu yang disepakati baik dengan pelunasan secara sekaligus (charge card) ataupun dengan pembayaran secara angsuran. ${ }^{3}$

Penggunaan kartu kredit di Indonesia mengalami penurunan pada tahun 2017 dibandingkan pada awal tahun 2017 jumlah kartu kredit tercatat 17,49 juta keping, Februari tercatat 17,52 juta keping, Maret tercatat 17,59 juta keping, April 17,66 juta keping, Mei tercatat 17,22 juta keping, Juni tercatat 16,77 juta keping, Juli tercatat 16,85 juta keping, namun pada bulan Agustus 2017 tercatat hanya 16, 89 juta keping. Menurut Deputi Gubernur BI Sugeng, hal ini terjadi karena jumlah pengguna kartu kredit sedang menjalani tahap konsolidasi, namun masih tetap dalam batas kewajaran, dalam arti pemegang kartu kredit benar-benar masyarakat yang layak dan mampu menggunakan limit kredit dengan baik dan bijak. Hal ini juga berkaitan dengan tentangperaturan kewajiban pelaporan transaksi kartu kredit pada tahun 2016 yang

\footnotetext{
2 Resa Raditio, Aspek Hukum Transaksi Elektronik:Perikatan, Pembuktian dan Penyelesaian Sengketa,(Yogyakarta: Graha Ilmu, 2014), hal.2-3.

3 Bank Indonesia, Peraturan Bank Indonesia No. PBI/11/11/ PBI/2009 Pasal 1 ayat (4) tentang Penyelenggaraan Kegiatan Alat Pembayaran Dengan Menggunakan Kartu. Lembaran Negara RI Nomor 64 DASP, Tambahan Lembaran Negara RI Nomor 5000 .
}

menjadi trigger penutupan kartu oleh nasabah. Bank Indonesia juga memberikan perlindungan konsumen bagi pengguna kartu kredit dengan kewajiban menggunakan PIN 6 digit untuk transaksi, pelarangan double swipe, dan surcharge, penurunan suku bunga kartu kredit dari 2,95\% menjadi 2,25\% per bulan. ${ }^{4}$

Bisnis pembiayaan konsumen meskipun sangat menarik tapi tidak berarti bisnis ini tidak memiliki resiko sama sekali, sebagaimana pemberian kredit, risiko akan tetap ada, seperti misalnya pada saat macetnya pembayaran tunggakan kartu kredit oleh konsumen. Meskipun penggunaan kartu kredit dikenal sangat praktis dan aman, sebenarnya pengguna kartu kredit masuk dalam lingkaran kehidupan yang dikendalikan oleh aktivitas hutang, semakin banyak kartu kredit yang dimilikinya, semakin bebas dalam membelanjakan uang plastiknya, otomatis akan semakin banyak hutang yang dimilikinya, meskipun secara sosial mereka dinobatkan menjadi warga masyarakat modern. Berbagai diskon, penawaran yang sangat menarik, pemilik kartu kredit akan dikondisikan sedemikian rupa agar selalu berbelanja, agar menjadi konsumen yang loyal.

Cara penggunaan kartu kredit yang cukup mudah dengan hanya membubuhkan tanda tangan, kemudian bank penerbit kartu akan membayarkan terlebih dahulu barang belanjaan milik konsumen, sekilas sangat memanjakan konsumen, namun sebenarnya anda mengeluarkan uang sendiri untuk membayar transaksi tersebut, bukan uang orang lain apalagi uang bank. Bank tidak memberikan secara gratis segala bentuk pembayaran yang mereka lakukan. Anda harus membayar tagihan sebelum jatuh tempo. Kenyamanan dan ketidakpekaan ini yang pada akhirnya sebagai awal mula bencana apabila terjadi berulang kali. ${ }^{5}$

Apabila terjadi kemacetan kredit konsumen, maka bank biasanya menggunakan jasa penagihan hutang yang dikenal dengan debt collector. Seringkali debt collector dalam melakukan jasa penagihan hutang bekerja secara tidak profesional bahkan kadang cenderung melakukan perbuatan melawan hukum,

\footnotetext{
4 https://finance.detik.com/moneter/d-3677481/sejak-awal2017-jumlah-kartu-kredit-terus-turun, diunduh pada 26 Februari 2017, pukul. 16.00 WIB.

5 Freddy Pieloor, Benahi Cara Hidup- Raih Kekayaandan Kesejahteraan, (Jakarta: PT. Elek MediaKomputindo, 2008), hal.92.
} 
sehingga akan menimbulkan kerugian bagi nasabah maupun bank penerbit kartu kredit, karena tidak sesuai dengan yang diharapkannya. Pernah terjadi sampai masuk ranah pidana karena debt collector melakukan kekerasan kepada nasabah bank sampai meninggal dunia, di Palembang debt collector mencabuli korban dan banyak kejadian lainnya.

\section{Permasalahan}

1. Apakah dasar hukum hubungan bank dengan debt collector?

2. Apakah dasar hukum pertanggung jawaban bank atas perbuatan melawan hukum yang dilakukan oleh debtcollector?

\section{Tujuan Penulisan}

1. Untuk mengetahui dasar hukum hubungan bank dengan debt collector.

2. Untuk mengetahui dasar hukum pertanggung jawaban bank atas perbuatan melawan hukum yang dilakukan oleh debt collector.

\section{Dasar Hukum Pembiayaan Konsumen}

Dasar hukum pembiayaan konsumen adalah perjanjian diantara para pihak berdasarkan asas kebebasan berkontrak, yaitu perjanjian antara pihak perusahaan finansial sebagai kreditur dan pihak konsumen sebagai debitur, sebagaimana yang diatur dalam Pasal1338 ayat (1) KUH Perdata yang menyatakan bahwa suatu perjanjian yang dibuat secara sah berlaku sebagai undang-undang bagi yang membuatnya. Pembiayaan konsumen juga diatur dalam Keppres No 61 tahun 1988 tentang Lembaga Pembiayaan yang kemudian ditindaklanjuti dengan Keputusan Menteri Keuangan No.1251/ KMK.013/1988 tentang Ketentuan dan Tata Cara Pelaksanaan Lembaga Pembiayaan, sebagaimana telah diubah dengan KeputusanMenteri Keuangan RI No.448/KMK.017/2000 tentang Perusahaan Pembiayaan dan Peraturan Bank Indonesia No 11/11/PBI/2009 tentang Penyelenggaraan Kegiatan Alat Pembayaran Dengan Menggunakan Kartu. ${ }^{6}$

Peraturan perundangan tentang perbankan tidak berlaku terhadap perusahaan pembiayaan ini karena keberadaan perusahaan finansial sangat berbeda dengan bank, sehingga secara substansif yuridis tidaklayak diberlakukan peraturanperbankan dan secara yuridis formal perusahaan pembiayaan bukan bank, oleh karena nya tidaklah tunduk pada peraturan perbankan, meskipun peraturan tersebut dalam bentuk undang-undang, kecualiundangundang tersebut menentukan sebaliknya. ${ }^{7}$

\section{Dasar Hukum Kartu Kredit}

Kartu kredit berfungsi untuk membayar pembelanjaan atas barang dan jasa maupun pengambilan uang tunai, yang pelunasannya dapat dilakukan secara mengangsur oleh pemegangnya. ${ }^{8}$ Dasar hukum kartu kredit tidak diatur secara tegas di dalam $\mathrm{KUH}$ Perdata maupun dalam KUHD, namun pengaturan pelaksanaan kegiatan kartu kredit di Indonesia adalah berdasarkan perjanjian antara para pihak sebagai dasar hukum sebagaimana yang diatur dalam Pasal 1338 ayat (1) KUHPerdata yang dikenal dengan asas kebebasan berkontrak, dengan syarat bahwa perjanjian kartu kredit tersebut dibuat tidak bertentangan dengan hukum atau kebiasaan yang berlaku.

Oleh karena itu pasal-pasal mengenai perikan dalam buku ketiga KUH Perdata juga berlaku terhadap perjanjian-perjanjian yang terkait dengan kartu kredit secara mutatismutandis. Selain itu pengaturan tentang kartukredit diatur dalam Keppres No.6 Tahun 1988 tentang Lembaga Pembiayaan dalam Pasal 2 ayat (1), Pasal 1 ayat (7) dan Pasal 3. Keputusan Menteri Keuangan No.1251/KMK.013/1998 tentang Ketentuan dan Tata Cara Pelaksanaan Lembaga Pembiayaan, sebagaimana telah diubah dengan Keputusan Menteri Keuangan RINo.448/KMK.017/2000 tentang Perusahaan Pembiayaan dan Peraturan Bank Indonesia No 11/11/PBI/2009 tentang Penyelenggaraan Kegiatan Alat Pembayaran Dengan Menggunakan Kartu. Undang-Undang No 7 Tahun 1992 tentang Perbankan sebagaimana yang diubah dengan Undang-Undang No.10 Tahun 1998 dan berbagai peraturan perbankan lainnya. ${ }^{9}$

\footnotetext{
7 Ibid.

8 Juli Irmayanto, Bank dan Lembaga Keuangan, (Jakarta: Penerbit Universitas Trisakti, 2009), hal. 185

9 Ibid, hal. 180-182.
} 


\section{Dasar Hukum Debt Collector di Indonesia}

Bank di dalam melakukan penagihan hutang, baik dengan menggunakan tenagapenagihan tersendiri atau dengan menggunakan jasa penagihan hutang dari perusahaan outsourching jasa penagihan piutang, bank diwajibkan untuk memastikan bahwa tenaga penagihan mematuhi peraturan etika penagihan hutang kartu kredit yang diatur dalam Pasal $17 \mathrm{~B}$ ayat (1), Pasal 17 B ayat (2), Pasal 17 B ayat (3) PBI 14/2012 tentang Perubahan Atas Peraturan Bank Indonesia Nomor 11/11/PBI/2009 Tentang Penyelenggaraan Kegiatan Alat Pembayaran Dengan Menggunakan Kartu dan Romawi VII Huruf D Angka 4b SEBI 2012 dan Romawi VII Huruf D Angka 4c SEBI 2012.

Surat Edaran Bank Indonesia Nomor 14/17/DASP tentang penyelenggaraan kegiatan alat pembaran dengan menggunakan kartu (APMK). Surat edaran ini merupakan aturan pelaksana dari Peraturan Bank Indonesia No. 14/2/PBI/2012 tanggal 6 Januari 2012 tentang Perubahan Atas PBI No. 11/11/PBI/2009 tentang Penyelenggaraan Kegiatan APMK. Aturan pelaksanaan yang diatur di dalam surat edaran nomor 14/17/DASP yang terbit tanggal 7 Juni 2012 tentang penagihan utang kartu kredit, yaitu:

1) Penagihan Kartu Kredit dengan menggunakan perusahaan penyedia jasa penagihan hanya dapat dilakukan terhadap tagihan Kartu Kredit yang telah macet berdasarkan kriteria kolektibilitas sesuai ketentuan Bank Indonesia yang mengatur mengenai kualitas kredit;

2) Kualitas pelaksanaan penagihan Kartu Kredit oleh perusahaan penyedia jasa penagihan harus sama dengan pelaksanaan penagihan Kartu Kredit yang dilakukan sendiri oleh Penerbit Kartu Kredit;

3) Tenaga penagihan telah memperoleh pelatihan yang memadai terkait dengan tugas penagihan dan etika penagihan sesuai ketentuan yang berlaku;

4) Identitas setiap tenaga penagihan ditatausahakan dengan baik oleh Penerbit Kartu Kredit;

Sedangkan pengaturan etika dalam penagihan kartu kredit sudah disetujui oleh asosiasi bank penyelenggara Alat Pembayaran dengan Menggunakan Kartu (APMK), adalah:
- Debt collector menggunakan kartu identitas resmi yang dikeluarkan Penerbit Kartu Kredit.

- Dilarang menggunakan cara ancaman, kekerasan dan/atau tindakan yang bersifat mempermalukan Pemegang Kartu Kredit;

- Penagihan dilarang dilakukan dengan menggunakan tekanan secara fisik maupun verbal;

- Penagihan dilarang dilakukan kepada pihak selain Pemegang Kartu Kredit;

- Penagihan menggunakan sarana komunikasi dilarang dilakukan secara terus menerus yang bersifat mengganggu;

- Penagihan hanya dapat dilakukan di tempat alamat penagihan atau domisili Pemegang Kartu Kredit;

- Penagihan hanya dapat dilakukan pada pukul 08.00 sampai denganpukul 20.00 sesuai wilayah waktu alamat Pemegang Kartu Kredit;

- Penagihan di luar tempat penagihan yang ditentukan atau di luar waktu yang telah ditentukan di atas, hanyadapat dilakukan atas dasar persetujuan dan/atau perjanjian dengan Pemegang Kartu Kredit terlebih dahulu;

- Penerbit Kartu Kredit juga harus memastikan bahwa perusahaan jasa penagihan juga mematuhi etika penagihan yang ditetapkan oleh asosiasi penyelenggara APMK. ${ }^{10}$

\section{Hubungan Bank dan Jasa Penagihan (Debt Collector)}

Bank adalah suatu badan usaha yang menghimpun dana dari masyarakat dalambentuk simpanan dan menyalurkannya dalambentuk kredit dan atau bentuk-bentuk lainnya, dalam rangka meningkatkan taraf hidup rakyat banyak ${ }^{11}$ Dalam dunia perbankan jasa penagihan (debt collector) dibutuhkanapabila terjadi kredit macet pada nasabahnya, pengertian debt collector adalah is

10 https://www.halomoney.co.id/blog/ditagih-debt-collector-gakusah-panik-baca-dulu-tips-ini, diunduh Pada 26 Februari 2017, pukul 20.00 WIB

11Indonesia, Undang-Undang tentang Perubahan atasUU No 7 Tahun 1992 tentang Perbankan, UU No.10tahun 1998, Lembaran Negara RI No 182, Tambahan Lembaran Negara RI No3790. 
theprocess of pursuing payments of debtsowed by individuals or businesses. An organization that specializes in debt collection is known as a collection agency or debt collector ${ }^{12}$ yangdapat diartikan proses pembayaran hutang yang harus dibayar oleh seseorang atau badan hukum, sebuah jasa penagihan yang mengkhususkan diri dalam penagihan hutang yang dikenal dengan agen penagihan atau debt collector.

Dari pengertian tersebut tugas debtcollector adalah menagih tunggakan kartu kredit nasabah bank yang udah jatuh tempo. Biasanya apabila hutang yang sudah jatuh tempo jumlahnya besar dan sudah tidak dibayar dalam jangka waktu yang lama, maka bank menggunakan jasa debt collector untuk menagih hutang-hutang nasabah. Beberapa kasus debt collector bertindak tidak secara profesional seperti kematian nasabah City Bank Irzen Okta yang dibunuh oleh debt collector pada tahun 2011 yang keberatan dengan jumlah tagihan kartu kredit yang tidak sesuai dimana pinjaman awal Rp.48.000.000,- menjadi Rp.100.000.000,-dimana bunga/rente/riba lebih besar dari pinjamannya, pada tahun 2009 Muji Harjo juga menjadi korban kekerasan yang dilakukan debt collector matanya nyaris buta karena dipukul matanya padahal sedang menggunakan kacamata dan menyebabkan harusoperasi $\quad \mathrm{t} \mathrm{u}$ lang mata denganmengeluarkan kocek untuk operasi Rp.70.000.000,,${ }^{13}$ belum lagi mantan Menkum Ham Patrialis Akbar juga pernah dimaki-maki dan diancam akan di black list di semua bank oleh debt collector City Bank gara-gara telat membayar tagihan kartu kredit yang sejumlah 1-2 juta rupiah. ${ }^{14}$

Setelah banyak terjadi kejadian kekerasan yang dilakukan oleh debt collector, Bank Indonesia akhirnya mengeluarkan Peraturan BI No.13/25/ PBI/2011 pada tanggal 9 Desember 2011 tentang Prinsip Kehati-hatian Bagi Bank Umum yang Melakukan Penyerahan Sebagian Pelaksanaan

12 https://en.wikipedia.org/wiki/Debt_collection,diunduh pada tanggal 26 Februari 2018, pukul. 15.00 WIB.

13 https://infoindonesiakita.com/2011/04/01/nasabah-citibank-mati-dibunuh-debt-collector/, diunduh pada Februari 2018, pukul. 17.00 WIB.

14 http://www.detiknews.com/read/2011/04/05/16351 4/1609106/608/patrialis-akbar-sakit-hati-dimaki-maki-debtcollector?nd991103605, diunduh pada 20Februari 2018, pukul. 17.00 WIB.
Pekerjaan Kepada Pihak Lain ${ }^{15}$. Diatur dalam Pasal $2^{16}$ danPasal $3^{17} \mathrm{PBI}$ ini. Akan tetapi PBI ini belum secara khusus mengatur standar operasional prosedur (SOP) mengenai alih daya penggunaan jasa pihak lain.

Kasus antara Standard Chartered Bank dan Ir. Victoria Silvia Beltiny mengenai kredit tanpa agunan sejak tahun 2004 dan lancar membayar tagihan kreditnya akan tetapi pada Mei 2009 mengalami kredit macet karena kesulitan keuangan, dan pada 7 September 2009 didatangi oleh debt collector dari Standard Chartered Bank dengan menawarkan reschedule dan Ir. Victoria Silvia Beltiny sepakat membayarnya sesuai kesepakatan akan tetapi Standard Chartered Bank menolak usulan tersebut dan malah mengintimidasi, meneror, menekan, baik secara langsung maupun tidak langsung melalui debt collector, telepon dan kepada teman-teman kantor dengan cara mencaci maki dan penyebaran ketidak mampuan membayar cicilan kepada semua rekan kerja hal ini membuat Ir. Victoria Silvia Beltiny menderita tekanan baik karena namabaiknya telah dicemarkan. Dalam kasus ini Mahkamah Agung mengeluarkan Putusan No:3192K/Pdt/2012 dengan memperbaiki amar Putusan Pengadilan Tinggi Jakarta No.529/PDT/2011/PT.DKI tertanggal 3 Januari 2012 yang menguatkan dan memperbaiki Putusan Pengadilan Negeri Jakarta Selatan No.151/PDT.G/2010/ PN.Jkt.Sel tertanggal 15 Juli 2010 dengan menyatakan bahwa Standard Chartered Bank telah melakukan perbuatan melawalan hukum dan menghukum tergugat secara tanggung renteng membayar ganti rugi kepada Ir. Victoria Silvia Beltiny sebesar Rp.1.000.000.000,(satu milyar rupiah).

Mengenai hubungan pihak bank dan debt collector tidak begitu jelas aturan hukumnya selain

15 Bank Indonesia, Peraturan BI tentang PrinsipKehati-hatian Bagi Bank Umum yang Melakukan Penyerahan Sebagian Pelaksanaan Pekerjaan Kepada Pihak Lain, Peraturan BI No.13/25/PBI/2011 Lembaran Negara RI Tahun 2011 No/131 DPNP, Tambahan Berita Negara RI Nomor 5263.

16(1) Bank dapat melakukan Alih Daya kepada Perusahaan Penyedia Jasa. Dalam melakukan Alih Daya, Bank wajib menerapkan prinsip kehati-hatian dan manajemen risiko.

17(1) Alih Daya sebagaimana dimaksud dalam Pasal 2 ayat (1) dilakukan Bank melalui perjanjian:pemborongan pekerjaan; dan/ atau penyediaan jasa tenaga kerja.

Bank wajib memastikan bahwa pelaksanaan pekerjaan yang dialihdayakan sesuai dengan perjanjian yang dibuat dan peraturan perundang-undangan yang berlaku.

Bank tetap bertanggung jawab atas pekerjaan yang dialihdaya- kan kepada Perusahaan Penyedia Jasa. 
daripada bentuk hubungan perjanjian pemberian kuasa dalam penagihan hutang kartu kredit. Hal inilah yang dalam prakteknya akan menimbulkan masalah di dalam prakteknya di lapangan. Dalam melakukan penagihan tunggakan kredit nasabah bank dapat dilakukan oleh karyawan bank sendiri dan jasa penagihan hutang atau pihak outsourching. Apabila yang melakukan penagihan adalah karyawan bank itu sendiri, maka karyawan bank tersebut melakukannya atas nama bank sebagai badan hukum dandapat dipertanggung jawabkan berdasarkan

pasal 1365 KUH Perdata apabila organ badan hukum melakukan perbuatan melawan hukum. ${ }^{18}$

Jadi apabila karyawan bank melakukan penagihan kartu kredit maka ia bertindak sebagai organ badan hukum (bank) dan bukan sebagai pribadi. Dapat dikatakan jika yang melakukan penagihan adalah pihak jasa penagihan kartu kredit (debt collector) merupakan perbuatan melanggar hukum di luar wewenang yang diberikan oleh badan hukum (bank) maka badan hukum tidak bertanggung jawab. Debt collector bertanggung jawab secara pribadi.

Di dalam hukum perdata pertanggung jawaban timbul karena perikatan yang dibuat. Buku ketiga KUH Perdata mengenai perikatan tidak memberikan definisimengenai perikatan. Para ahli hukum perdata sepakat bahwa sumber perikatan sebagaimana yang diatur dalam Pasal 1233KUH Perdata kurang lengkap, karena di luar yang diatur dalam pasal tersebut masih ada sumber perikatan lain, yaitu doktrin, hukum yang tidak tertulis $\mathrm{d}$ a $\mathrm{n}$ putusan Hakim. ${ }^{19}$

Salah satu definisi hukum perikatan (verbintenis recht) menurut ahli adalah: "Hubungan hukum antara dua pihak, dimana disatu pihak ada hak dan di lain pihak ada kewajiban, sedang prestasi perikatan menurut buku III KUH Perdata paling tidak apda akhirnya harus bisa dijabarkan dalam sejumlah uang tertentu". ${ }^{20}$

18 M.A. Moegni Djojodirjo, Perbuatan Melawan Hukum, Cet. Ke 2, (Jakarta: Pradnya Paramita, 1982),hal. 176.

19Mariam Darus Badrulzaman, Kompilasi Hukum Perika- tan,

Cet.1, (Bandung: PT. Citra Aditya Bakti,2001), hal. 9.

20J. satrio, Hukum Perikatan: Perikatan yang Lahirda- ri

Perjanjian, Buku I, (Bandung: PT. Citra AdityaBakti, 2001), hal.5.

\section{Pertanggung jawaban Bank atas Perbuatan Melawan Hukum yang di- lakukan oleh Debt Collector}

Perbuatan melawan hukum berasal dari istilah Belanda (onrechtmatige daad). Perbuatan melawan hukum lebih merupakan bentuk struktur normadari pada substansi yang ada di dalam Pasal 1365 KUHPerdata ${ }^{21}$.Perbuatan melawan hukum menurut Prof Rosa Agustina adalah: "Perbuatan yang melanggar hak (subyektif) orang lain atau perbuatan (atau tidak berbuat) yang bertentangan dengan kewajiban menurut undangundang atau bertentangan dengan apa yang menurut hukum tidak tertulis yang seharusnya di jalankan oleh seseorang dalam pergaulannya dengan sesama warga masyarakat dengan mengingat adanya alasan pembenar menurut hukum". ${ }^{22}$

Perbuatan melawan hukum secara konseptualnya tidaklahterbatas pada perbuatan melawan hukum yang yang dilakukan oleh diri pribadi, namun termasuk juga perbuatan yang dilakukan oleh orang lain serta barang-barang yang berada dalam penguasaannya sebagaimana yang diatur dalam pasal 1367 KUH Perdata, perbuatan anak yang belum dewasa menjadi tanggung jawab orang tua atau walinya yang diatur dalam pasal 1369 KUH Perdata, perbuatan melawan hukum atas jiwa dan tubuh manusia yang diatur dalam Pasal 1370 KUH Perdata dan perbuatan melawan hukum terhadap nama baik seseorang termasuk penghinaan yang diatur dalam pasal 1372-1380 KUH Perdata.

Dalam konsep perbuatan melawan hukum sebagaimana yang diatur dalam pasal 1365 KUH Perdata terdapat syarat kesalahan dimana pelaku perbuatan melawan hukum hanyalah bertanggung jawab atas kerugian yang ditimbulkannya, apabila perbuatan tersebut dapat dipersalahkan kepadanya. ${ }^{23}$ Pada dasarnya prinsip adanya kesalahan yang terdapat

21 "Tiap perbuatan yang melanggar hukum danmembawa kerugian kepada orang lain, mewajibkan orang yang menimbul- kan kerugian itu karena kesalahannya untuk menggantikan keru- gian tersebut."

22 Rosa Agustina, Perbuatan Melawan Hukum, Cet.1, (Ja- karta: Program Pascasarjana Fakultas Hukum, Universitas Indo- nesia, 2003), hal.4-5.

23 Ibid, hal. 46 
dalam pasal 1365 KUH Perdata adalah "liability based on fault" dengan beban pembuktian ada pada penderita. Hal ini sejalan dengan ketentuan pasal 1865 KUH Perdata yang menentukan bahwa setiap orang yang mendalilkan bahwa ia mempunyai suatu hak, meneguhkanhaknya sendiri maupun membantah hak orang lain, menunjuk pada suatu peristiwa diwajibkan membuktikan adanya hak atau peristiwa tersebut. Hubungan sebab akibat (causalitas) dalam perbuatan melawan hukum berkaitan dengan apakah adanya hubungan causal atara perbuatan melawan hukum dengan kerugian yang ditimbulkan, sehingga pelaku dapat dipertanggung jawabkan. ${ }^{24}$

Hal-hal yang dapat menghilangkan atau menghapuskan sifat perbuatan melawan hukum suatu perbuatan, dimana berakibat hukum bahwa perbuatan melawan hukum yang dilakukan akan menjadi suatu perbuatan yang benar karena adanya suatu keadaan yang meniadakan, menghapus atau menghilangkan sifat melawan hukumnya. Ada 4 (empat) alasan yang dapat menghapus sifat melawan hukum, yaitu keadaaan memaksa (overmacht), pembelaan darurat atau terpaksa, melaksanakan ketentuan undang-undang dan melaksanakan perintah atasan. Ke empat alasan ini diakui sebagai alasan pembenar yang dibagi dalam 2 (dua) kategori yang Bersifat objektif menyangkut perbuatannya antara lain meliputi: melaksanakan hak pribadi, pembelaan diri (noodweer) dan keadaan memaksa (over macht) dansifat subyektif menyangkut pelakunya, meliputi: melaksanakan perintah kepegawaian, dan hak menghakimi sendiri (eigen richting), sebagaimana pelaksanaan pasal 1155 KUH Perdata. ${ }^{25}$

Selain alasan pembenar tersebut di atas juga dikenal kontraktor independen yaitu pembelaan dari pihak yang memberi pekerjaan atas perbuatan melawan hukum dari orang yang ia berikan pekerjaan. Definisi kontraktor independen bergantung kepada kenyataan, bahwa tidak seperti seorang karyawan, seorang kontrak- tor independen dapat mempertahankan kontrol atas pekerjaan yang mereka lakukan, sedangkan individu atau perusahaan yang mambayar mereka hanya dapat mengontrol produk akhir atau jasa. Seorang kontraktor independen melakukan pekerjaan atas perintah majikan, namun di dalam melakukan pekerjaannya majikan tidak campur tangan dalam hal-hal teknis menyangkut pekerjaan tersebut, ketidak tahuan ini dapat digunakan sebagai suatu bentuk pembelaan jika tersebut melakukan perbuatan melawan hukum.

Dari beberapa kasus yang ada perusahaan dianggap bertanggung jawab atas "torts" dari seorang idependent contractor, yaitu seorang pekerja bawahan. Di Ingris berlaku peraturan yang sama dimana dianggap sebagai suatu pengecualian atas dasar prinsip umum commonlaw, bahwa seorang pemberi perintahpada prinsipnya tidak bertanggung jawab untuk perbuatan melawan hukum yang dilakukan oleh orang yang tidak memiliki hubungan bawahan. ${ }^{26}$

Mengenai pertanggung jawaban majikan yang diatur dalam Pasal 1367 ayat (3) KUH Perdata tidak hanya mengenai tanggung jawab dalam ikatan kerja saja, termasuk kepada seseorang yang diluar ikatan kerja, dimana terjadi pemberian perintah kepada orang lain untuk melakukan suatu pekerjaan tertentu, asal saja orang yang diperintahkan melakukan pekerjaannya secara sendiri-sendiri baik baik atas pimpinannya sendiri atau telah melakukan pekerjaanya tersebut atas petunjuknya, yang mana juga diatur dalam pasal 1601 a KUH Perdata, tanggung jawab majikan atas perbuatan-perbuatan melawan hukum dari karyawankaryawannya, bahwa persetujuan perburuhan adalah persetujuan dengan mana pihak yang satu, si buruh, mengikatkan dirinya untuk dibawah perintahnya, pihak yang lain, si majikan, untuk suatu waktutertentu
$24 \quad$ Ibid, hal. 66.

25Wirjono Prodjodikoro, Perbuatan Melanggar Hukum Dipandang dari Sudut Hukum Perdata, Cet.1, (Bandung: Mandar maju, 2000), hal.40-54.
$26 \quad$ Agustina, Op.Cit, hal.117. 
melakukan pekerjaan dengan menerima upah. ${ }^{27}$

Sehubungan dengan pengertian di atas maka perbuatan melawan hukum debt collector yang merupakan pekerja alih daya (out sourching) maka apa yang dilakukannya tetap menjadi tanggung jawab bank sebagai pihak yang memberikan perintah kepadanya untuk menagih tunggakan piutang nasabah kartu kredit. Dimana karyawan atau pekerja alih daya (out sourching) ini yang ditempatkan di perusahaan pengguna out sourching akan mengikuti sop aturan kerja sebagaimana yang berlaku pada perusahaan di tempat dia dipekerjakan. Debt collector di dalam melakukan suatu perbuatan melawan hukum karena ia sedang melakukan perintah dari atasannya. Sebagai contoh pada saat seorang debt collector melakukan penagihan terhadap tunggakan hutang nasabah, hal ini semata-mata dilakukan karena adanya suatu perjanjian alih daya, dimana setiap perbuatan yang debtcollector lakukan tentu merupakansebuah perbuatan yang sudah diatur dan diketahui oleh perusahaan (bank) sebagai pihak pemberi kerja.

Jika kita melihat kepada Surat Edaran Bank Indonesia No.11/10/DADP tahun 2009 tentang Penyelenggaraan Kegiatan Alat Pembayaran Menggunakan Kartu pada bagian D poin b mengenai kerjasama penerbit dengan pihak lain bahwa penerbit (bank) menjamin bahwa penagihan yang dilakukan pihak lain harus dilakukan dengan cara-cara yang tidak melanggar hukum. Kemudian pada poin c bahwa dalam perjanjian kerjasama antara penerbit dan pihak lain untuk melakukan penagihan transaksi kartu kredit tersebut harus memenuhi klausula tentang tanggung jawab penerbit terhadap segala akibat hukum yang timbul akibat dari kerjasama dengan pihak lain tersebut. ${ }^{28}$

Dalam kasus kematian nasabah City Bank Irzen Okta Untuk kasus kematian nasabah kartu kredit, BI menemukan 2 (dua) tindakan Citibank yang secara telak melanggar Peraturan Bank Indonesia (PBI) 11/11/2009 tentang Alat Pembayaran den-

27 Moegni Djojodirjo, Op.Cit, hal.128 dan 131.

28 Surat Edaran Bank Indonesia No.11/10/DASP tentang Penyelenggaraan Kegiatan Alat Pembayaran dengan Menggunakan Kartu. 13 April 2009. gan Menggunakan Kartu (APMK). Pertama, soal kontrak kerja sama Citibank dengan pihak penagih utang. Dalam perjanjian dinyatakan segala tanggung jawab akhir ada di pihak penagih. "Padahal, PBI menyebutkan, segala permasalahan dalam penagihan harus menjadi tanggung jawab bank," kata Difi Ahmad Johansyah, Pelaksana Tugas Direktur Perencanaan Strategis dan Hubungan Masyarakat BI. Kedua, Citibank bersalah dalam penagihan utang. Hasil audit BI menunjukkan, utang Irzen masih berstatus kolektibilitas dua (dalam perhatian khusus). Artinya, Citibank tak boleh menyerahkan penagihan utang ke pihak lain. PBI menyebutkan, bank boleh menggunakan pihak ketiga setelah tunggakannya masuk kolektibilitas empat (diragukan) dan lima (macet). ${ }^{29}$

Sesuaidenganhukum perjanjian, maka perjanjian kerjasama penyediaan jasa pekerjaantara perusahaan alih daya debtcollector dan perusahaan pengguna(bank) dalam melakukan pekerjaan penagihan hutang yang ditempatkan dan bekerja pada perusahaan alih daya, dimana karyawan tersebut telah melakukan perjanjian kerja dengan perusahaan alih daya sebagai hubungan ketenagakerjaan, dimana dalam salah satu klausulnya bahwa karyawan akan ditempatkan dan bekerja di perusahaan alih daya (outsourching) sebagai debtcollector.

Oleh karena itu apabilaterjadi seorang debt collector melakukan pekerjaan melawan hukum dalam melakukan tugasnya menagih tunggakan hutang kepada nasabah kartu kredit tetap menjadi tanggung jawab bank sebagai pihak yang memberikan perintahkepadanya sebagai bawahan sebagaimana yang diatur di dalam pasal 1365 KUH Perdata yaitu : "Tiap perbuatan melanggar hukum yang membawa kerugian kepadaseorang lain, mewajibkan orang yang karena salahnya menerbitkan kerugian itu, mengganti kerugian tersebut".

\section{Kesimpulan dan Saran}

Dasar hukum mengenai hubungan bank dengan

$29 \mathrm{~h} \mathrm{t} \mathrm{t} \mathrm{p} \mathrm{s} \mathrm{:} \mathrm{/} \mathrm{/} \mathrm{n} \mathrm{a} \mathrm{s} \mathrm{o} \mathrm{n} \mathrm{a} 1$. k o m p a s. c o m / read/2011/04/27/09280128/bi.nyatakan.citibank.bersalah, diunduh padatanggal 20 Februari 2017, pukul. 13.00 WIB. 
debt collector adalah Surat Edaran Bank Indo- nesia No.11/10/DASP tentang Penyelenggaraan Kegiatan Alat Pembayaran dengan Mengguna- kan Kartu pada tanggal 13 April 2009, Peraturan Bank Indonesia No.13/25/PBI/2011 tanggal 9 Desember 2011 tentang Prinsip Kehati-hatian bagiBank Umum yang Melakukan Penyera- han Sebagian Pelaksanaan Pekerjaan Kepada Pihak Lain.

Dasar hukum pertanggungjawaban bank atas perbuatan melawan hukum yang dilakukan oleh debt collector adalah berdasarkan pasal 1365 KUH Perdata, dimana tindakan debt collector yang merupakan pekerja alih daya.(outsourch- ing) yang bekerja berdasarkan perjanjian penye- diaan jasa penagihan telah terikat dengan per- janjian dimana debt collector menjadi pekerja/ karyawan yang melakukan pekerjaan penagihan hutang kepada nasabah bank, di dalam melaku- kan pekerjaan tentulah mengikuti aturan kerja sesuai dengan SOP perusahaan (bank) pada perusahaan pengguna alih daya oleh karenya maka perbuatan yang dilakukannya tetap men- jadi tanggung jawab bank sebagai pihak yang memberikan perintah kepadanya. Bank Indonesia sebaiknya membuat peraturan mengenai debt collector sebagai perusahaan alih daya (outsourching) supaya jelas apa kewanangan debt collector di dalam melaku- kan pekerjaannya dan mengatur masalah pertanggung jawaban secara hukum apabila terjadi perbuatan melawan hukum di dalam melakukan pekerjaannya, siapakah yang harus bertanggung jawab.

Bank sebagai perusahaan penguna jasa penagihan hutang, harus membuat Standar Oprasional Prosedur (SOP) mengenai apa yang harus dilakukan oleh debt collector di dalam menjalankan tugasnya dalam menagih hutang nasabah kartu kredit.

\section{Daftar Pustaka}

Buku

Freddy Pieloor, Benahi Cara Hidup-RaihKe- kayaan dan Kesejahteraan, Jakarta: PT.Elek Media Komputindo, 2008.

Juli Irmayanto, Bank dan LembagaKeuangan, Jakarta: Penerbit UniversitasTrisakti, 2009. J. satrio, Hukum Perikatan: Perikatan yang Lahir dari Perjanjian, Buku I, Bandung: PT.Citra Aditya Bakti, 2001.

Mariam Darus Badrulzaman, Kompilasi Hukum Perikatan, Cet.1, Bandung: PT.Citra Aditya Bakti, 2000.

M.A. Moegni Djojodirjo, Perbuatan Melawan Hukum, Cet. Ke 2, Jakarta: PradnyaParamita.

Munir Fuady, Hukum Tentang Pembiayaan, Band- ung: PT. Citra Aditya Bakti, 2014.

Resa Raditio, Aspek Hukum TransaksiElektronik: Perikatan, Pembuktian dan Penyelesaian Sen- gketa, Yogyakarta: GrahaIlmu, 2014.

Rosa Agustina, Perbuatan Melawan Hukum, Cet.1, Jakarta: Program Pascasarjana Fakultas Hukum, Universitas Indonesia, 2003. 
Wirjono Prodjodikoro, PerbuatanMelanggar Hu- kum Dipandang dari Sudut Hukum Perdata, Cet.1, Bandung: Mandarmaju, 2000.

\section{Peraturan Perundang-undangan}

Subekti dan R.Tjitrosudibio, Kitab Undang- undang Hukum Perdata (Burgerlijk Wetboek), Jakarta: PT.Pradnya Paramita,1992.

Indonesia, Undang-Undang tentangPerubahan atas UU No 7 Tahun 1992 tentang Perbankan, UU No.10 tahun 1998,LN No 182, TLN No3790.

Bank Indonesia, Peraturan BI tentang PrinsipKehati-hatian Bagi Bank Umum yang Melakukan Penyerahan Sebagian Pelaksan- aan Pekerjaan Kepada Pihak Lain, Peraturan BI No.13/25/PBI/2011 Lembaran Negara RI Tahun 2011 No/131 DPNP, Tambahan Berita Negara RI Nomor 5263.

Bank Indonesia, Peraturan Bank Indone- sia No.14/2/PBI/2012 tentang Perubahan Atas Peraturan Bank Indonesia No.11/11/ PBI/2009 tentang Penyelenggaraan Kegiatan Alat Pembayaran Dengan menggunakan Kartu pada tanggal 6 Januari 2012.

Bank Indonesia, Peraturan Bank Indonesia No. PBI/11/11/PBI/2009 Pasal 1 ayat (4) tentang Penyelenggaraan Kegiatan Alat Pembayaran Dengan Menggunakan Kartu. Lembaran Negara RI Nomor 64 DASP, Tam- bahan Lembaran Negara RI Nomor 5000.

\section{Internet}

https://finance.detik.com/moneter/d-3677481/ sejak-awal-2017-jumlah-kartu-kredit-terusturun, diunduh pada 26 Februari2017, pukul. 16.00 WIB.

https://finance.detik.com/moneter/d-3677481/ sejak-awal-2017-jumlah-kartu-kredit-terusturun, diunduh pada $26 \mathrm{~F}$.

r evwfa bnhbvgnhfebruari2017, pukul. 16.00 WIB.

https://www.halomoney.co.id/blog/ditagih-debt- collector-gak-usah-panik-baca-dulu- tipsini, diunduh Pada 26 Februari 2017, pukul 20.00WIB.

https://en.wikipedia. org/wiki/Debt_collection, diunduh padatang- gal 26 Februari 2017, pukul. 15.00 WIB.

https://infoindonesiakita.com/2011/04/01/ nasabah-citibank-mati-dibunuhdebt- collector/,diunduh pada 20 Februari 2017, pukul. 17.00 WIB. http://www.detiknews.com/read/2011/04/05/163

514/1609106/608/patrialis-akbar-sakit-hatidimaki-maki-debt-collector?nd991103605, diunduh pada 20Februari 2017, pukul. 17.00 WIB.

h t t p s : / / n a s i o n a 1 . k o m p a s . c o m / read/2011/04/27/09280128/bi.nyatakan. citibank.bersalah,diunduh pada tanggal 20 Februari 2017, pukul. 13.00 WIB 